\title{
A PARTIAL SHORT ARM DELETION OF CHROMOSOME 20:46, XY, del(20)(p11)
}

\author{
Keiji Kogame, Tomomasa Fukuhara, * Atsuhiko MaEda, * \\ and Yuji KuDo* \\ Department of Central Clinical Laboratory \\ * Department of Pediatrics, Hirosaki University Hospital. \\ Hirosaki University School of Medicine, Hirgsaki, Japan
}

\begin{abstract}
Summary We have identified a partial deletion of the short arm of chromosome 20 in a 5-year-old boy from parents having normal phenotype and karyotype. His major anomalies were mild mental retardation, congenital heart disease, chest deformity, spina bifida, kyphoscoliosis, inguinal hernia, and preauricular fistula, The clinical findings were compared with those of two patients reported previously as a partial deletion $20 \mathrm{p}$.

The activity of adenosine deaminase in the patient's red blood cells was within normal range, suggesting that the gene locus for the enzyme, which has been previously assigned to chromosome 20 , may not present on $\mathrm{p} 11 \rightarrow$ pter of chromosome 20 .
\end{abstract}

\section{INTRODUCTION}

Reports of $F$ group chromosomal abnormalities have been relatively infrequent. Abnormalities of chromosome 20 which were identified by Q- and/or G-banding techniques have been reported in complete trisomy 20 (Wahlström et al., 1976; Pan et al., 1976), trisomy 20 mosaicism (Pallister et al., 1976), partial trisomy 20p resulting from a translocation (Krmpotic et al., 1971; Francke, 1972; Šubrt and Brychnáč, 1974; Cohen et al:, 1975; Taylor et al., 1976), ring 20 (Atkins et al., 1972; Uchida and Lin, 1972; Faed et al., 1972; Herva et al., 1977), and so far only two reports of a partial deletion 20p have been found (Loiodice et al., 1970; Kalousek and Therien, 1976). Other structural changes of $\mathrm{F}$ group chromosome have been found in bone marrow cells in association with various haematological disorders, such as polycythemia vera (Reeves et al., 1972).

We present here a case of partial short arm deletion of chromosome 20 and compare our case with two previous cases, and discuss the common features of the clinical findings among these three patients. Using patient's red blood cells, we attempt to determine the gene locus for adenosine deaminase which has been pro- 
visionally assigned to chromosome 20 by somatic cell hybridization techniques (Tischfield et al., 1974).

\section{CASE REPORT}

The patient, a full-term male infant, was born on October 1, 1971 when the father was 29 and the mother 23 years old. The family history showed no consanguinity and no affected member with any congenital abnormality. There were no abortions or stillbirths. Both parents and his younger sister are of normal phenotype. The pregnancy and the delivery were uneventful. Birth weight was $2,150 \mathrm{~g}$. For reasons of asphyxia and cyanosis at birth, he was treated in an incubator for 38 days. The neonatal period was complicated by jaundice. At 18 days of age, a heart murmur was detected and broad anterior fontanelle and separation of sagittal sutures were also noted. He was admitted to our pediatric ward at Hirosaki University Hospital on November 17,1971 with a diagnosis of possible hydrocephalus and congenital heart disease. Karyotypes of the patient were identified as 46,XY, ${ }^{2} \mathrm{Fp}$ - He was discharged on March 7, 1972. He experienced an upper respiratory tract infection followed by cyanosis, dyspnea and myotonic convulsion in December 1972. Bilateral inguinal hernia was operated at 2 years and 2 months of age. On January 10, 1977 he was readmitted to our pediatric ward for heârt murmur and persistence of weakness and fatigue.. At that time, his weight was $11 \mathrm{~kg}$, and length $92 \mathrm{~cm}$. His facial configuration gave an abnormal and idiotic impression (Fig. 1). Clinical examinations revealed antimongoloid slant, epicanthus, saddle nose, malocculusion, high arched palate, enamel hypoplasia of teeth, preauricular fistula, hearing loss, chest deformity, spina bifida, kyphoscoliosis, joint dislocation, enormous toes, thin limbs, swan neck deformity of fingers; coarse hair, and congenital heart disease (pulmonary stenosis and left superior vena cava). Course of his development was as follows: holding up head 6 months, sitting up 1 year, creeping 2 years, standing 3 years, speech 2 years, walking 3 years. According to Suzuki-Binet method IQ was 69 and gross motor was 1 year 11 months, fine motor 3 years 4 months, speech 4 years, and social 3 years. His physical growth and psychomotor development were mildly retarded.

Haematological investigations were as follows: haemoglobin was $13.2 \mathrm{~g} / \mathrm{dl}$, hematocrit $39.3 \%$, red blood cell $5.12 \times 10^{6} / \mathrm{mm}^{3}$, white blood cell $8,200 / \mathrm{mm}^{3}$ and platelets $23.8 \times 10^{4} / \mathrm{mm}^{3}$. The preparation of peripheral blood smears revealed normal findings. Normal laboratory findings included urinalysis, serum levels of sodium, potassium, chloride, calcium, inorganic phosphate, total protein, total bilirubin, glucose, blood urea nitrogen, cholesterol, phospholipid, triglyceride, lipoprotein, and serum activity of glutamic oxaloacetic transaminase, glutamic pyruvic transaminase, lactic dehydrogenase, gamma-glutamyl transpeptidase and leucine amino peptidase. Thyroid function and kidney function tests showed normal findings. The serum levels of $\operatorname{IgG}, \operatorname{IgA}$ and $\operatorname{IgM}$ were normal. 


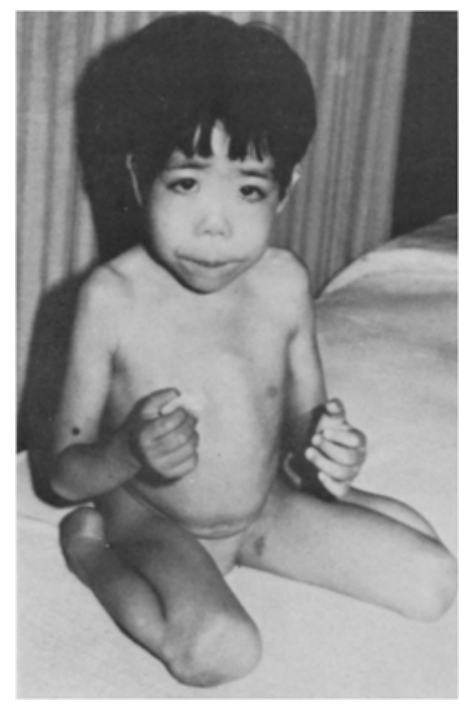

Fig. 1. Facial appearance of the patient at age of 5 years. Note antimongoloid slant, epicanthus, and saddle nose.

For the gene marker studies, the activity of adenosine deaminase of the patient's red blood cells was measured by the modified method of Letnansky and Seelich (1958). The average and standard deviation of the enzyme activity of 15 samples from early childhoods was $68.4 \pm 6.6$ moles adenosine/g $\mathrm{Hb} / \mathrm{hr}$ and the enzyme activity of the patient was 78.0 moles adenosine/g $\mathrm{Hb} / \mathrm{hr}$ which was determined to be within normal range.

\section{CYROGENETIC STUDIES}

Chromosomal analyses of the patient and his parents were performed on peripheral lymphocyte cultures using conventional procedures. Lymphocytes were incubated for 72 hours in RPMI 1640 culture media. Fibroblasts were not investigated. Chromosomal analyses have been carried out on two separate occasions. The first examination was made on December 1, 1971 according to the conventional Giemsa staining and the results showed that the modal number of the patient was 46. Twenty cells were karyotyped and the apparent abnormalities were the lack of one $F$ group chromosome and the excess of a chromosome similar to $G$ group. The extra chromosome had no satellites and its short arm was more distinctive than that of the $\mathrm{Y}$ chromosome. This chromosome was tentatively interpreted as a $\mathrm{F}$ group chromosome in which the short arm was partially deleted.

The second examination was made on December 10, 1975 with the fluorescence technique (Caspersson et al., 1970) and a modified Giemsa banding method of Sumner et al. (1971). It became apparent that the extra chromosome of the patient 


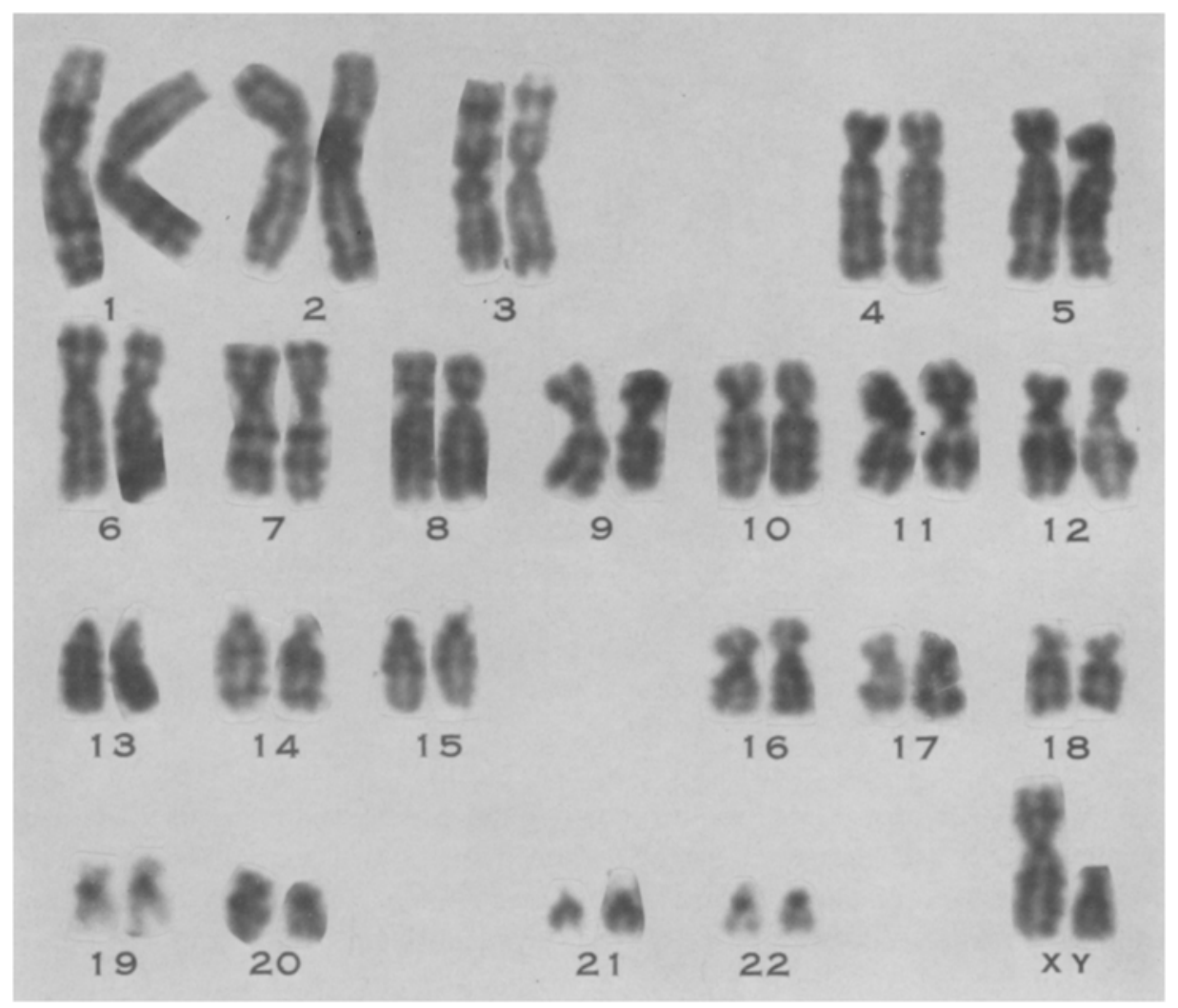

Fig. 2. G-banded karyotype of the patient: 46, XY, del(20) (p11).

was not a member of group $\mathrm{G}$, but the long arm of chromosome 20 with a partial deletion of the short arm. All the other chromosomes of the patient showed a normal banding pattern. The karyotype can, therefore, be represented as: $46, \mathrm{XY}$, $\operatorname{del}(20)$ (p11) or $46, \mathrm{XY}, \operatorname{del}(20)$ (qter $\rightarrow \mathrm{p} 11:$ ) according to the nomenclature by Paris Conference (1971) (Figs. 2 and 3). No abnormalities were found in his parents' karyotypes.

\section{DISCUSSION}

To our knowledge, only two cases of a partial short arm deletion of chromosome 20 are reported previously (Loiodice et al., 1970; Kalousek and Therien, 1976). The main clinical features of our case are compared with those of the two reported cases, and are summarized in Table 1.

The features of our case common to the others are congenital heart disease, thoracic vertebral anomaly, and growth and developmental retardation. In the 


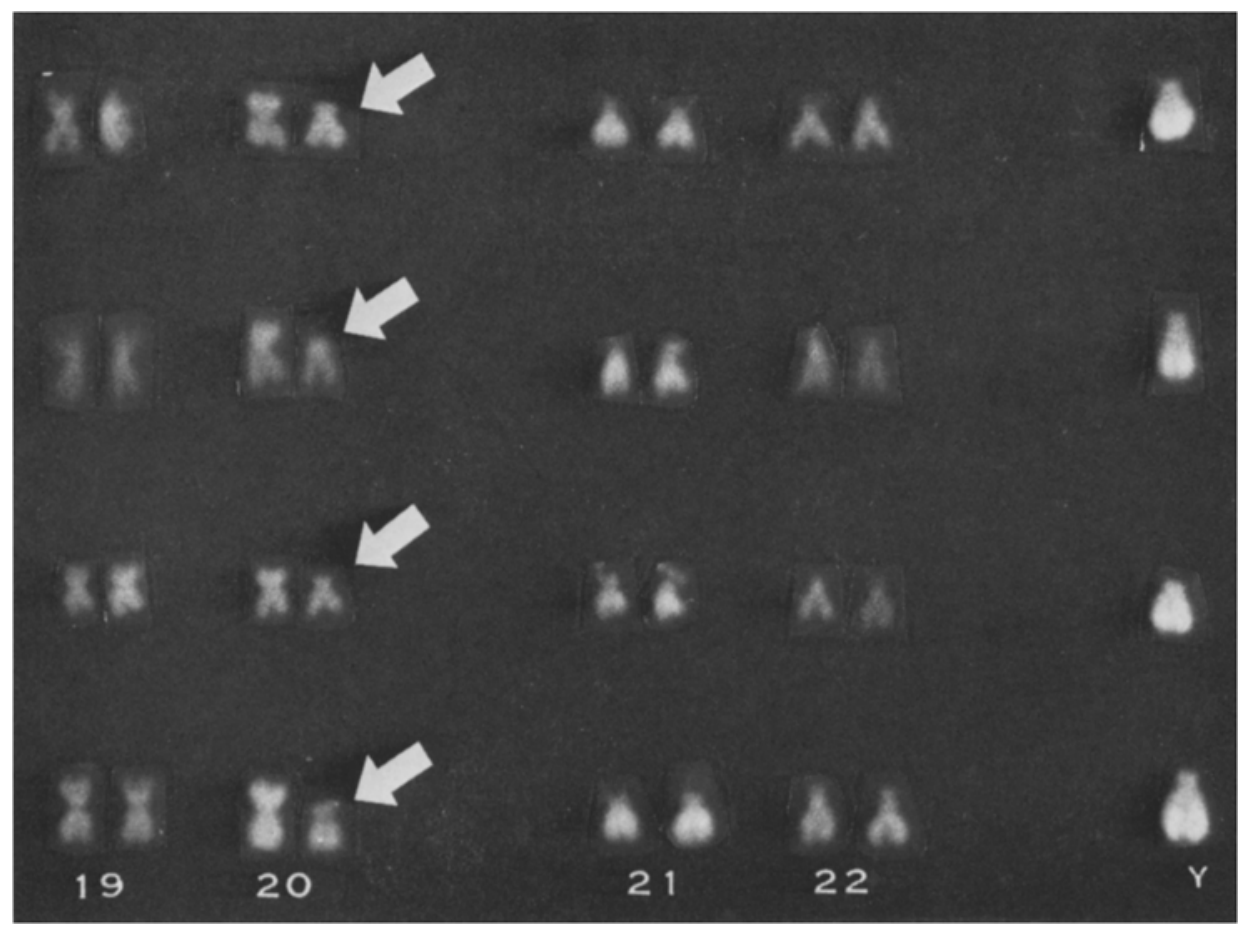

Fig. 3. Q-stained partial karyotypes of the patient. Arrow indicates chromosome 20 with partial deletion of the short arm (20p11 $\rightarrow$ pter).

report of Loiodice et al. (1970), the patient's phenotypically mormal father had a similar chromosomal abnormality. As have been pointed by Kalousek and Therien (1976) the report by Loiodice et al. (1970) lacked detailed cytogenetic description and documentation of the diagnosed deletion of the short arm of chromosome 20. It was hence deduced that the karyotype to the patient's father might be a translocation between the short arm of chromosome 20 and some other chromosome. The patient described by Kalousek and Therien (1976) had the same chromosomal abnormality to our patient who had a karyotype of deletion $20 \mathrm{p} 11$.

Ring chromosomes are also recognized as a type of deletion in which there is a minute loss from the terminal ends of both chromosome arms. Two cases of non-mosaic ring chromosome 20 have been described by Atkins et al. (1972) and Herva et al. (1977), and two mosaic cases by Uchida and Lin (1972) and Faed et al. (1972). All of the four cases have common clinical features including behaviour problems, low grade mental deficiency and epilepsy. Epilepsy has not been observed in the above mentioned three patients with a partial $20 \mathrm{p}$ deletion.

Developmental retardation and vertebral anomaly have been observed in various cases with complete trisomy 20 (Pan et al., 1976) as well as trisomy 20 with mosa- 
Table 1. Comparison of main clinical features in 3 cases of deletion of short arm of chromosome 20.

\begin{tabular}{|c|c|c|c|}
\hline & Loiodice et al. & Kalousek and Therien & Present case \\
\hline Sex (Age) & Male (5 days) & Female (11 months) & Male ( 5 years) \\
\hline Birth weight (g) & 2,350 & 2,570 & 2,150 \\
\hline $\begin{array}{l}\text { Growth and } \\
\text { development }\end{array}$ & Retardation & Retardation & Retardation \\
\hline Face & not stated & Flat & Normal \\
\hline Eyes & not stated & Normal & $\begin{array}{l}\text { Anti-mongoloid slant } \\
\text { Epicanthus }\end{array}$ \\
\hline Nose & $\begin{array}{l}\text { Deviation of the nasal } \\
\text { septum }\end{array}$ & Low nose bridge & Saddle \\
\hline Mouth & not stated & Small, long philtrum & $\begin{array}{l}\text { Malocculusion } \\
\text { Enamel bypoplasia-teeth }\end{array}$ \\
\hline Palate & not stated & Normal & High arched \\
\hline Ears & not stated & $\begin{array}{l}\text { Small ears with thick } \\
\text { and overfolded herix }\end{array}$ & Hearing loss \\
\hline Chin & not stated & Short & Normal \\
\hline Neck & not stated & Short & Normal \\
\hline \multirow[t]{4}{*}{ Skeleton } & $\begin{array}{l}\text { Wide pituitary fossa } \\
\text { Rib fusion }\end{array}$ & $\begin{array}{l}\text { Absent pair of ribs } \\
\text { Butterfly-shaped thoracic } \\
\text { vertebral bodies }\end{array}$ & $\begin{array}{l}\text { Chest deformity } \\
\text { Joint dislocation }\end{array}$ \\
\hline & Kyphosis & & Kyphoscoliosis \\
\hline & Hemispondyless & & Spina bifida \\
\hline & Neonatal osteoscoliosis & & \\
\hline Fingers and & not stated & Talipes equinovarus & Enormous toes \\
\hline toes & & Deep plantar furrows & $\begin{array}{l}\text { Swan neck deformity of } \\
\text { fingers }\end{array}$ \\
\hline \multirow[t]{4}{*}{ CHD } & Right ventricular & Mitral atresia & Pulmonary stenosis \\
\hline & hypertrophy & Common ventricle & Left superior vena cava \\
\hline & Right axis deviation & $\begin{array}{l}\text { Infundibular pulmonary } \\
\text { stenosis }\end{array}$ & \\
\hline & & $\begin{array}{l}\text { Left pulmonary branch } \\
\text { stenosis }\end{array}$ & \\
\hline \multirow[t]{2}{*}{ Others } & Right kryptorchidism & $\begin{array}{l}\text { Redundant skin on the } \\
\text { neck }\end{array}$ & Inguinal hernia \\
\hline & Phlebitis & $\begin{array}{l}\text { Mid-ileal atresia with a } \\
\text { microcolon }\end{array}$ & Coarse hair \\
\hline
\end{tabular}

icism (Pallister et al., 1976) and partial trisomy 20p (Krmpotic et al., 1971; Šubrt and Brychnáč, 1974; Taylor et al., 1976). It seems that vertebral anomaly, i.e. kyphoscoliosis, may be correlated with anomaly of chromosome 20. Further cases with $20 \mathrm{p}$ - will provide a better clinical delineation of this abnormality.

The gene locus for adenosine deaminase has been assigned to chromosome 20 by somatic cell hybridization techniques (Tischfield et al., 1974). However, it is yet unknown whether this gene locus is located on the long arm or short arm of chromosome 20. Taylor et al. (1976) have reported that adenosine deaminase 
activity was not affected in two patients with partial trisomy $20 \mathrm{p}$ derived from a $t(18 ; 20)$ translocation. In the present study adenosine deaminase activity of the patient was within normal range. These facts suggest that the gene locus for the enzyme is not located on the deleted part of the short arm of chromosome 20 , but presumably on the long arm or the proximal part of the short arm, i.e. $20 \mathrm{pl} 1 \rightarrow$ qter.

Acknowledgments The authors are indebted to Professor Hajime Kudo, Department of Central Clinical Laboratory and Professor Yukio Izumi, Department of Pediatrics, Hirosaki University Hospital, Hirosaki University School of Medicine, for valuable suggestions and reading manuscript.

\section{REFERENCES}

Atkins, L., Miller, W. L., and Salam, M. 1972. A ring-20 chromosome. J. Med. Genet. 9: 377-380. Caspersson, T., Zech, H. J. and Johansson, C. 1970. Differential binding of alkylating fluorochromes in human chromosomes. Exptl. Cell Res. 60: 315-319.

Cohen, M. M., Davidson, R. G., and Brown, J. A. 1975. A familial F/G translocation t(20p-; $22 q+$ ) observed in three generations. Clin. Genet. 7: 120-127.

Faed, M., Morton, H. G., and Robertson, J. 1972. Ring F chromosome mosaicism (46, XY, 20r/ $46, \mathrm{XY}$ ) in an epileptic child without apparent haematological disease. J. Med. Genet. 9: 470473.

Francke, U. 1972. Quinacrine mustard fluorescence of human chromosomes: Characterization of unusual translocations. Amer. J. Hum. Genet. 24: 189-213.

Herva, R., Saarinen, I, and Leikkonen, L. 1977. The r(20) syndrome. J. Med. Genet. 14: 281-283.

Kalousek, D. K. and Therien, S. 1976. Deletion of the short arms of chromosome 20. Hum. Genet. 34: 89-92.

Krmpotic, E., Rosenthal, I. M., Szego, K., and Bocian, M. 1971. Trisomy F (?20) report of a 14q/F(?20) familial translocation. Ann. Genet. 14: 291-299.

Letnansky, K. and Seelich, F. 1958. Untersuchungen über die Aktivität der Adenosin-Desaminase im Plasma bei Krebskrankheiten unter besonderer Berücksichtigung des Bronchialcarcinoms. Klin. Wschr. 36: 826-828.

Loiodice, G., Rovetta, D. G., Bellicini, G., Callura, G., and Bergamo, F. 1970. Malformazioni multiple congenite in un bambino portatore di una anomalia cromosomica del gruppo $F(46 / \mathrm{XY}$, 20-p), figlio di un soggetto, clinicamente sano, affetto da analoga malformazione cromosomica. Minerva Pediat. 22: 1084-1088.

Pallister, P. D., Hermann, J., Meisner, L. F., Inhorn, S. L., and Opitz, J. M. 1976. Trisomy-20 syndrome in man. Lancet i: 431.

Pan, S. F., Fatora, S. R., Haas, J. E., and Steele, M. W. 1976. Trisomy of chromosome 20. Glin. Genet. 9: 449-453.

Paris Conference. 1971. Standerdization in human cytogenetics (1972). Birth Defects: Original Article Series, 8 (7). National Foundation-March of Dimes, New York.

Reeves, B. R., Lobb, D. S. and Lawler, S. D. 1972. Identity of the abnormal F-group chromosome associated with polycythemia vera. Hum. Genet. 14: 159-161.

Šubrt, I. and Brychnáč, V. 1974. Trisomy for short arm of chromosome 20. Humangenetik 23: 219-222.

Sumner, A. T., Evans, H. J., and Buckland, R. A. 1971. New technique for distinguishing between human chromosomes. Nature New Biol. 232: 31-32.

Taylor, K. M., Wolfinger, H. L., Brown, M. G., Chadwick, D. L., and Francke, U. 1976. Partial 
trisomy 20p derived from a $\mathrm{t}(18 ; 20)$ translocation. Hum. Genet. 34: 155-162.

Tischfield, J. A., Creagan, R. P., Nichols, E., and Ruddle, F. H. 1974. Assignment of adenosine deaminase to chromosome 20. Cytogenet. Cell Genet. 13: 160-163.

Uchida, I. A. and Lin, C. C. 1972. Ring formation of chromosomes Nos. 19 and 20. Cytogenetics 11: $208-215$.

Wahlström, J., Borsgard, J., and Sebel, K.-G. 1976. A case of trisomy 20?. Clin. Genet. 9: 187-191. 